\title{
THE PSYCHOLOGICAL DEVELOPMENT PROMOTION OF CHILDREN IN PORTUGUESE DAYCARE CONTEXT
}

\author{
Maria da Luz Vale-Dias \\ Institute of Cognitive Psychology, Human and Social Development \\ Faculty of Psychology and Educational Sciences - University of Coimbra, Coimbra, Portugal \\ valedias@fpce.uc.pt \\ Ana Mafalda Pinho \\ Institute of Cognitive Psychology, Human and Social Development \\ Faculty of Psychology and Educational Sciences - University of Coimbra, Coimbra, Portugal \\ anacastropinho@hotmail.com \\ Maria de Lourdes Cró \\ Superior Education School of Coimbra \\ Coimbra, Portugal \\ Graciete Franco-Borges \\ Institute of Cognitive Psychology, Human and Social Development \\ Faculty of Psychology and Educational Sciences - University of Coimbra, Coimbra, Portugal
}

Fecha de Recepción: 24 Febrero 2018

Fecha de Admisión: 10 Abril 2018

\section{ABSTRACT}

This research falls within the area of developmental psychology, particularly with regard to the promotion of the child's psychological development considering the educational context. It was specifically intended to study the importance to the psychological development of children of its sojourn at early ages in daycare educational contexts, basing the pedagogical intervention in a proposed program, based on the High/Scope curricular approach (Post \& Hohmann, 2011), as well as on the Portage model (Williams \& Aiello, 2009). Assuming as a primary objective the promotion of the psychological development of these children, it becomes a pressing need to reflect on educational interventions for early ages, being also of significant importance that these are properly supported in scientific theories of human development. We advocated, then, to develop a researchaction with a quasi-experimental component, whose results would allow to envisage a curriculum for the context of childcare, which could activate the psychological development of children and qualitatively raise the educational intervention. Thus, in this study, with the participation of children $(\mathrm{N}=59)$ aged about two years old, and also with their kindergarten teachers $(N=4)$, it was intended, through a comparative study between groups of children, subjected or not to the above men- 
tioned program and under this research, to know its impact on the psychological development using, in the pre and post-test phases, observation/appreciation grids of this development for children in childcare age. With particular regard to the data collected is possible to advance that children who were part of the experimental groups, which were subject to an intervention program, showed higher gains in the post-test phase at the level of development of motor skills, language, cognitive development and affective and relational development, comparing to the children of the control groups, who experienced a natural educational intervention. Implications are presented.

Keywords: child psychological development; early childhood education; development promotion program

\section{INTRODUCTION}

Within the scope of the formal educational provision for children from zero to three years of age, in Portugal, the one that has the greatest recognition is daycare. According to the Portuguese law on Education, this context presents itself as a socio-educational social response, where children must be provided with adequate conditions for their harmonious and global development (Ministério da Educação, 2000). However, although it is recognized as important for the child's development, there is still no definition of a curriculum or specific pedagogical orientations for this context (Pinho, Cró \& Vale-Dias, 2013, 2016). Kindergarten teachers working in this educational context receive initial training that mainly prepares them to promote the development of children from the age of three when they enter preschool education (Portugal, 2000, 2009; Vasconcelos, 2001). Although more specific legal recommendations have been made for Education from the age of zero to three years (Vasconcelos, 2011), the training of kindergarten/nursery teachers is still considered to be incomplete when it comes to intervention among children at an early age in daycare. Considering this gap, it is necessary to deepen the research on the promotion of the development of children in this educational context, in order to consolidate the lines for pedagogical training in such context.

The thematic of this work proposes an innovative perspective to conceive the education in the context of daycare different from the one that has been more usual in Portugal. At a time when, finalIy, one begins to realize that quality education is a fundamental requirement for the psychological development of any child and that educational interventions and/or contexts of dubious quality can be a risk to the lives of children, it is crucial to identify the factors most favorable to that development. Issues related with the quality of educational interventions and/or educational contexts have recently been discussed, as they are being viewed as closely related to the evolution of countries. The Organization for Economic Co-operation and Development has advocated that quality education has been perceived as the most plausible way to bridge social inequalities and promote entrepreneurship. It also stresses that there are indeed several theories that relate education to human development in broad terms and economic development, stating that several theories "explicitly connect investment in human capital development to education, and the role of human capital in economic development [...]" (OECD, 2013, p. 286). In fact, human learning and evolution is related to education and with the personal development. It is being seen like an integrated process that causes a qualitative transformation in the individual's mental structure (Oliveira, Martins, Rodrigues, Inácio \& Pocinho, 2012).

In this sense and targeting a positive return, we will try to explore some aspects in child development promotion, contributing to insight a reflection around issues that generate the quality of the intervention in the context of daycare. We would also like to contribute to reflect on what it really means to educate within the context in question since it is a context that integrates children with very particular characteristics such as precocity in relation to age and the consequent adult depend- 
ence. In this regard, according to some authors, the younger the child, the more dependent on others will be in order to organize itself and grow (Strecht, 2001). This fact underlines the role of others and the need for quality in early interactions, including the context of daycare. Stressing the importance of the development context, recent literature states that "It is recognised now that children's development is not simply linear; rather, children's development plateaus, accelerates and deviates according to the environment and context of their lives" (Blandford \& Knowles, 2013, p. 80).

Considering "solid evidence that underscores the role of positive, early experiences in strengthening brain architecture" (Shonkoff, 2010, p. 365), seeing the period until 36 months of age as one of the most important for learning and development of the child's cerebral structure (Hawley, 2009), and assuming as a primary objective the promotion of the psychological development at early ages (Division of Child Development, 2012; NICHD, 2005; Shonkoff, 2010), it becomes a pressing need to reflect on educational interventions in this context, being also of significant importance that these are properly supported in scientific theories of human development and investigation. Thus, in this research, with the participation of children with about two years of age, as well as with their kindergarten/nursery teachers, it was intended, through a comparative study between groups of children who were subject to and not subject to a specific program in daycare, to evaluate its impact on the psychological development. The framework of the present study refers to the area of developmental psychology, particularly with regard to the promotion of the child's psychological development considering the educational context. It was specifically intended to study the importance to the psychological development of children of its sojourn at early ages in daycare educational contexts, guiding the pedagogical intervention by a proposed program, based on the High/Scope curricular approach (Post \& Hohmann, 2011), as well as on the Portage model (Williams \& Aiello, 2009). The general hypothesis considers that the use, in the context of daycare, of a curricular program elaborated within the perspective of the child's psychological development will be revealed as a relevant factor for the psychological development of the children.

\section{METHOD}

\section{Participants}

This research used a convenience sample and implied the participation of children ( $N=59 ; 31$ male) with about two years of age ( $M=2,51$ years), in Portuguese daycare centers, as well as their kindergarten/nursery teachers ( $N=4 ; 3$ female) contribution. The effect of professional and academic career of the kindergarten/nursery teachers involved in this study was controlled. Thus, two of them had a longer career (16 years) and less recent formal training, compared to the other two which had a shorter career ( 3 and 5 years) and more recent training. The teachers ages varied between 29 and 42 years old.

In the experimental groups (using a proposed pedagogical program), the mean permanence time of children in daycare was $8.62 \mathrm{~h}(S D=0.86)$ and in control groups (no program) it was $8.81 \mathrm{~h}$ $(S D=0.81)$. The difference was not statistically significant $(F(1,58)=0.83, p=.366)$. Also, there were no significant differences concerning to the mean age $(F(1,58)=2.860, p=.098)$ and gender $\left(\chi^{2}(1)=0.80, p=.371\right)$ of children in experimental and control groups.

\section{Procedure and Instruments}

The present study consists on the development of a research-action with a quasi-experimental component. So, also including in the progression of the study the feedback information obtained from the kindergarten/nursery teachers, with this research it was intended, through a comparative study between groups of children (two experimental groups and two control groups), subject or not 
to a proposed intervention program, to evaluate its impact on the children's psychological development, using, in the pre and post-test phases, observation/appreciation grids of diverse dimensions of this development for children in childcare age. For the evaluation of the impact of the curricular program, in the constitution of the control and experimental groups, we considered important to control the factor relative to the effect of the professional and academic course of the kindergarten/nursery teacher. Thus, two experimental groups were considered, both characterized by the use of a specific curricular program but differing according to the teachers' professional and academic trajectory, that is, shorter/more recent or longer/less recent. The two control groups, without program use, were also constituted on the basis of this distinction.

The pedagogical intervention in experimental groups followed a proposed program (Pinho, 2015), based on the principles of High/Scope curricular approach (Post \& Hohmann, 2011), as well as on the Portage model (Williams \& Aiello, 2009) with a duration of eight weeks. In control groups, there was no interference on the strategies usually used by the kindergarten/nursery teacher.

To collect data, the research used sociodemographic questionnaires concerning children and teachers. In order to evaluate the program's impact on the children psychological development, data collection was also made through the use of Observation/Appreciation Grids of Dimensions of Development for children in childcare age (Pinho, 2008, 2015), which were used in the pre-test and post-test phases. To collect qualitative data on pedagogical strategies and conceptions, interviews with the kindergarten/nursery teachers were also conducted.

\section{RESULTS}

The purpose of this study was to understand the importance of activating the psychological development of children at early ages in educational contexts of daycare, founding the educational intervention in a program elaborated and based on the guidelines of the High-Scope curricular approach (active learning and key experiences) and the Portage model. Thus, one of the main ways to verify this influence was to compare experimental groups with control groups, before and after the implementation of the intervention program to which children in experimental groups were subjected, evaluating the increase or magnitude of the change after that program, assessing its effects on children's psychological development and, at the same time, comparing that increase with the increment observed in the control groups. Thus, all children in the pre-test and post-test phases were evaluated in development of motor skills (psychodevelopment), development of expressive language, cognitive development and affective and relational development (emotional intelligence).

It will be displayed the mean scores in the pre and post-test for the experimental and control groups regarding these development dimensions. Using ANOVA and, when appropriate, its nonparametric equivalent Mann-Whitney $U$ test, the magnitude of the increase of children's development from pre-test to post-test evaluation was compared considering control and experimental groups.

\section{Development of Motor Skills (psychodevelopment)}

According to the graphic below (Graphic 1), we find that the starting point of the experimental groups $(M=12.21 ; S D=3.50)$, in the Development of Motor Skills (psychodevelopment), is lower than the starting point of the control groups $(M=16.90$; $S D=3.40)$; and, on average, both the control groups and the experimental groups increase scores from the pre-test to the post-test. However, the analysis of the increment from pre-test to post-test reveal that, on average, the magnitude of change (Table 1) was higher in experimental groups than in control groups, and the difference was statistically significant $(F(1,57)=5.584, p=.022)$. The magnitude of change between pre-test and post-test was obtained by subtracting from the post-test score the score obtained on the pre-test. 
Graphic 1 - Mean scores in the pre-test and post-test for the experimental and control groups in Development of Motor Skills (psychodevelopment).

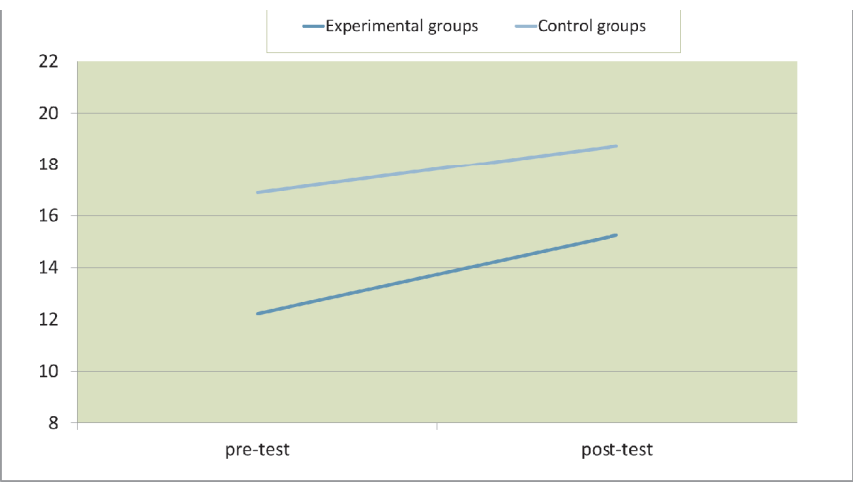

Table 1.

Means and standard deviation of the difference between pre-test and post-test for experimental and control groups concerning Motor Skills

\begin{tabular}{lcccc}
\hline \multicolumn{1}{c}{ Groups } & Minimum & Maximum & Mean & SD \\
\hline Experimental Groups & 1 & 7 & 3.04 & 2.01 \\
Control Groups & -1 & 6 & 1.84 & 1.88 \\
\hline
\end{tabular}

\section{Expressive Language Development}

In terms of Expressive Language development (Graphic 2), as in the case of Development of Motor Skills (psychodevelopment), we find that the starting point of the experimental groups $(M=10.21 ; S D=5.40)$ is lower than the starting point of the control groups $(M=15.23 ; S D=6.08)$, and both the control groups and the experimental groups increase scores on average from the pre-test to post-test evaluation. But, as previously, the magnitude of change (Table 2) was statistically higher in experimental groups $(U=210.000, p=.001)$.

Graphic 2 - Mean scores in the pre-test and post-test for the experimental and control groups in Expressive Language Development.

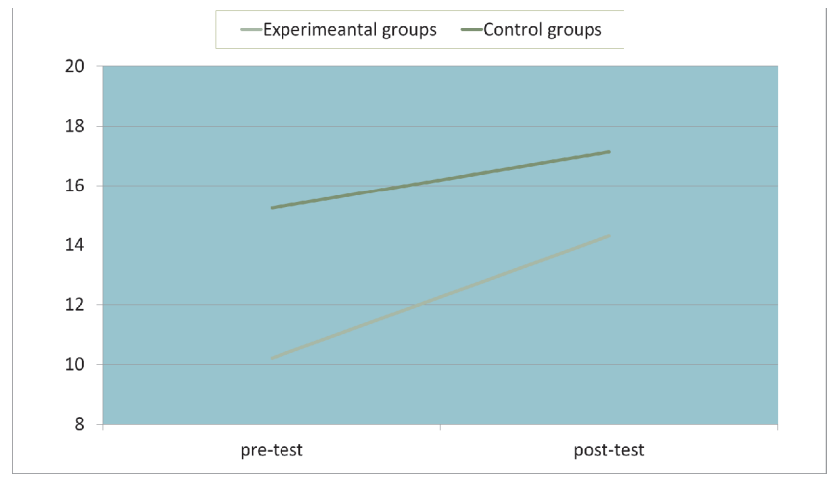




\section{THE PSYCHOLOGICAL DEVELOPMENT PROMOTION OF CHILDREN IN PORTUGUESE DAYCARE CONTEXT}

Table 2. Means and standard deviation of the difference between pre-test and post-test for experimental and control groups concerning Expressive Language Development

\begin{tabular}{lcccc}
\hline \multicolumn{1}{c}{ Groups } & Minimum & Maximum & Mean & SD \\
\hline Experimental Groups & 0 & 9 & 4,07 & 2,61 \\
Control Groups & -1 & 17 & 1,90 & 3,60 \\
\hline
\end{tabular}

\section{Cognitive Development}

According to Graphic 3, with regard to Cognitive Development, we discover again that the starting point of the experimental groups $(M=8.57 ; S D=4.53)$, is lower than the starting point of the control groups $(M=17.29 ; S D=4.56)$, and on average an increase is observed in experimental and control groups from the pre-test to the post-test scores. Once again, we find that the magnitude of the change from pre-test to post-test (Table 3 ) is significantly higher in the experimental groups $(\mathrm{U}=242.50, p=.003)$.

Graphic 3 - Mean scores in the pre-test and post-test for the experimental and control groups in Cognitive Development.

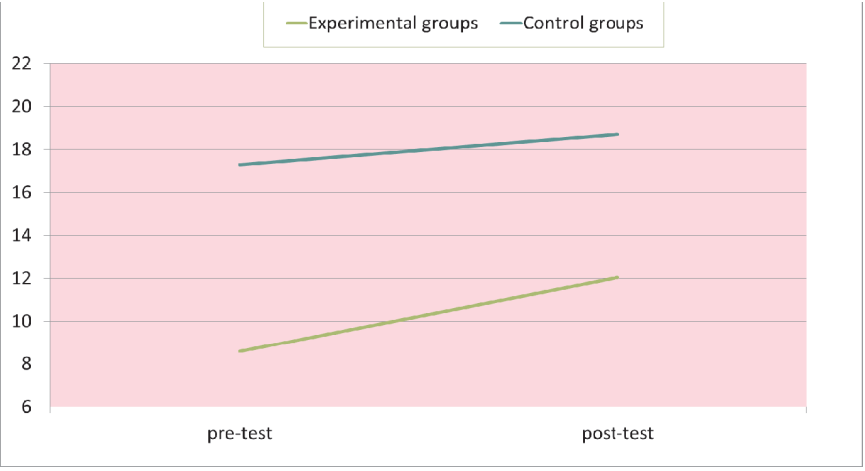

Table 3. Means and standard deviation of the difference between pre-test and post-test for experimental and control groups concerning Cognitive Development

\begin{tabular}{lcccc}
\hline \multicolumn{1}{c}{ Groups } & Minimum & Maximum & Mean & SD \\
\hline Experimental Groups & -1 & 11 & 3.46 & 3.04 \\
Control Groups & 0 & 4 & 1.42 & 1.29 \\
\hline
\end{tabular}

\section{Affective and Relational Development (emotional intelligence)}

Regarding to the Affective and Relational Development (emotional intelligence), according to Graphic 4, we can verify that the scores of the control groups (Pre-test: $M=10.21 ; S D=3.27$ ) were superior to those of the experimental groups (Pre-test: $M=16.29 ; S D=5.14)$. Once more, both the experimental groups and the control groups increased scores on average from the pre-test to the post-test phase. Concerning to the magnitude of change between these two phases of evaluation, 
we observe (Table 4) that on average the increase in this dimension was significantly superior in experimental groups $(F(1,57)=39.191, p=.000)$.

Graphic 4 - Mean scores in the pre-test and post-test for the experimental groups and for the control groups in Affective and Relational Development (emotional intelligence).

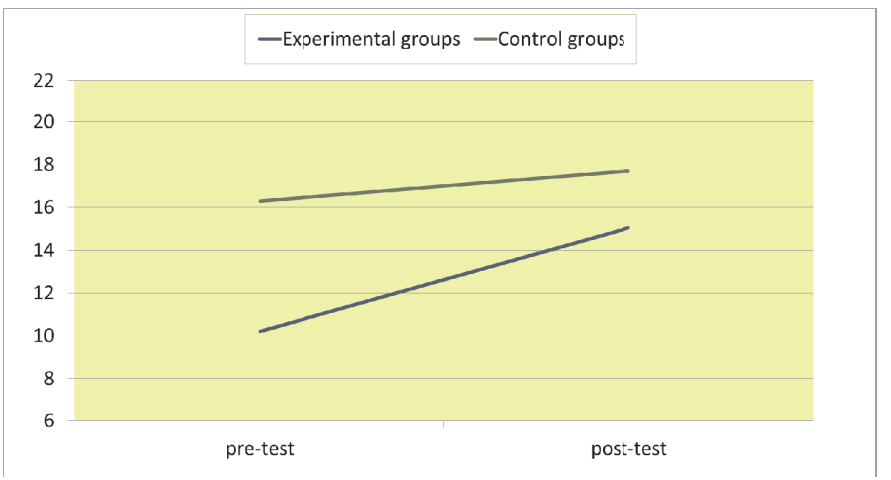

Table 4.

Means and standard deviation of the difference between pre-test and post-test for experimental and control groups concerning Affective and Relational Development

\begin{tabular}{lcccc}
\hline \multicolumn{1}{c}{ Groups } & Minimum & Maximum & Mean & SD \\
\hline Experimental Groups & 0 & 7 & 4.82 & 2.07 \\
Control Groups & -1 & 6 & 1.42 & 2.09 \\
\hline
\end{tabular}

\section{DISCUSSION AND CONCLUSIONS}

This study aimed to contribute to the reflection on the importance of the educational context in the first three years of life and also on the need of changes in social, political, economic and cultural contexts that interfere in the childhood education policy in Portugal. We advocated, then, to develop a research-action with a quasi-experimental component, whose results would allow to envisage a curriculum for the context of childcare, which could activate the psychological development of children and qualitatively raise the educational intervention.

It is important to note that, contrary to what has been happening for some years in other countries (e.g., Burchinal, Cryer, Clifford \& Howes, 2010; Cassidy, Buell, Pugh-Hoese \& Russell, 1995; Kreader, Ferguson \& Lawrence, 2005; Lally, 2009; Recchia \& Beck, 2014), there is a shortage of Portuguese research that deepens the role of educational strategies and contexts at an early age in promoting children's development. This fact points to a need of more research in order to consolidate or revise models.

Although there were no differences between the control and experimental groups considering the time of permanence in daycare, children who were part of the experimental groups, which were subjected to an intervention program aiming at the activation of the psychological development, showed higher gains (magnitude of change), from the pre-test to the post-test evaluation phase, regarding to Development of Motor Skills (psychodevelopment), Expressive Language 
Development, Cognitive Development and Affective and Relational Development (emotional intelligence), comparing to the children of the control groups, who experienced a natural educational intervention and started with a better position. These results are somewhat convergent with literature supporting the need and success of scientific informed curricular approaches for the promotion of development at early ages (e.g., Andrade \& Santos, 2012; Post \& Hohmann, 2011; Williams \& Aiello, 2009)

Despite some limitations related to the fact of using a convenience sample and to the practical impossibility of random assignment of the children to experimental and control groups, this study contributes to highlight the need for, on the one hand, rigorous observation/evaluation of children's development and, on the other hand, the elaboration of educational programs that activate their development in the context of daycare centers as recommended in previous literature (e.g., Field, 2008; Mustard, 2006). So, it becomes essential a pedagogical intervention founded on the knowledge of the child's development and the application of a curricular program that activates the psychological development of the child of early ages, based on a scientific curricular approach.

With particular regard to the data collected and obtained results it is possible to advance that activating the psychological development of precocious age children in a responsive and intentional way is a demanding task that requires in-depth knowledge of the development process and their promotion strategies. This is one of the essential paths to excellence in educational intervention.

\section{REFERENCES:}

Andrade, S., \& Santos, P. (2012). Experiential Approach in Education: A Response to Children's Emotional Problems. Procedia - Social and Behavioral Sciences, 69, 942 - 951. D0I: 10.1016/i.sbspro.2012.12.019

Blandford, S. \& Knowles, C. (2013). Developing Professional Practice 0-7. New York: Routledge.

Burchinal, M. R., Cryer, D., Clifford, R. M., \& Howes, C. (2010) Caregiver Training and Classroom Quality in Child Care Centers. Applied Developmental Science, 6(1), 2-11. D0I: 10.1207/S1532480XADS0601_01

Cassidy, D. J., Buell, M. J., Pugh-Hoese, S., \& Russell, S. (1995). The effect of education on child care teachers' beliefs and classroom quality: Year one evaluation of the TEACH early childhood associate degree scholarship program. Early Childhood Research Quarterly, 10(2), 171-183.

Division of Child Development (2012). Infant-Toddler Zone Handbook, Revised. North Carolina: Child Development, Department of Health and Human Services.

Hawley, T. (2000). Starting smart: How Early Experiences Affect Brain Development. Zero to Three. Retrieved from https://www.theounce.org/wp-content/uploads/2017/03/StartingSmart.pdf

Kreader, J. L., Ferguson, D. \& Lawrence, S. (2005). Impact of training and education for caregivers of infants and todlers. Child Care and Early Education - Research Conections, 3, 1-7.

Lally, J.R. (2009). The Science and Psychology of Infant-Toddler Care. How an Understanding of Early Learning Has Transformed Child Care. Zero to Three, 47-53. Retrieved from http://silversprings.njuhsd.com/documents/young\%20parents/infant\%20toddler\%20care/lally_30-21.pdf

Ministério da Educação. (2000). A educação pré escolar e os cuidados para a infância em Portugal: Relatório preparatório. Lisboa: ME.

Mustard, J.F. (2006). Early childhood development and experience-based brain development -the scientific underpinnings of the importance of early child development in a globalized world. Canada: The Brookings Institute.

NICHD Early Child Care Research Network (Ed.) (2005). Child Care and Child Development: Results of the NICHD Study of Early Child Care and Youth Development. NY: Guilford Press. 
OECD (2013). Development Co-operation Report 2013: Ending Poverty [em linha]. OECD Organisation for EconomicCo-operation and Development. Retrieved from http://dx.doi.org/10.1787/dcr-2013-en

Oliveira, A. S.; Martins, L. L.; Rodrigues, L. A.; Inácio, P. A. \& Pocinho, M. (2012). Avaliação da personalidade em contexto educativo. In L. S. Almeida, B. D. Silva \& A. Franco (Orgs.), Atas do II Seminário Internacional "Contributos da Psicologia em Contextos Educativos" (pp. 1627-1638). Braga: Centro de Investigação em Educação (CIEd) - Instituto de Educação - Universidade Minho.

Pinho, A. M., Cró, M. L. \& Vale-Dias, M. L. (2013). A formação de educadores de infância: práticas adequadas ao contexto educativo de creche. Revista Portuguesa de Pedagogia, 1(47), 109-125. DOI: 10.14195/1647-8614_47-1_6

Pinho, A. M., Cró, M.L., \& Vale-Dias, M.L. (2016). Promoción del desarrollo psicológico en Portugal: El contexto educativo de las guarderías. Paideia, 59, 99-120. http://www.revistapaideia.cl/index.php/PAIDEIA/article/view/120/118

Pinho, A.M. (2008). A avaliação do desenvolvimento pessoal e social dos 0 aos 3 anos (Dissertação de mestrado não publicada). Aveiro: Universidade de Aveiro.

Pinho, A.M. (2015). 0 contexto educativo de creche como promotor do desenvolvimento psicológico da criança (Dissertação de Doutoramento não Publicada). Faculdade de Psicologia e de Ciências da Educação, Universidade de Coimbra, Coimbra.

Portugal, G. (2000). Educação de bebés em creche: perspectivas de formação teóricas e práticas. Revista GEDEI, 1, 85106.

Portugal, G. (2009). Desenvolvimento e aprendizagem na infância. In A educação das crianças dos 0 aos 12 anos (pp. 33 67). Lisboa: Conselho Nacional de Educação.

Post, J., \& Hohmann, M. (2011). Educação de bebés em infantários: cuidados e primeiras aprendizagens. Lisboa: Fundação Calouste Gulbenkian.

Recchia, S. L., \& Beck, L. M. (2014) Reflective Practice as "Enrichment": How New Early Childhood Teachers Enact Preservice Values in Their Classrooms. Journal of Early Childhood Teacher Education, 35(3), 203-225, DOI: 10.1080/10901027.2014.936074

Shonkoff, J. P. (2010), Building a New Biodevelopmental Framework to Guide the Future of Early Childhood Policy. Child Development, 81, 357-367. D0I: 10.1111/j.1467-8624.2009.01399.x

Strecht, P. (2001). Interiores: uma ajuda aos pais sobre a vida emocional dos filhos. Lisboa: Assírio \& Alvim.

Vasconcelos, T. (2011). CNE - Recomendação n.- 3/2011 - A educação dos 0 aos 3 anos. Diário da República, 2. aㅗ série - N. $79-21$ de Abril, 2011.

Vasconcelos, V. (2001). Formação dos profissionais de educação infantil: reflexões sobre uma experiência. In V. Didonet (Org.), Educação infantil: a creche um bom começo (pp. 98 111). Brasília: Em Aberto.

Williams, L. \& Aiello, A. (2009). O inventário Portage operacionalizado: intervenção com famílias. São Paulo: MEMNON. 
